INDO GLOBAL JOURNAL OF

PHARMACEUTICAL SCIENCES

ISSN 2249- 1023

\title{
Enzymatic Treatment of Cotton Fabric with Cellulase from Amorphophallus paeoniifolius
}

\author{
Sakshi Bansal, Mehul Singhal, Neeraj Wadhwa* \\ Department of Biotechnology, Jaypee Institute of Information Technology, Noida, Uttar Pradesh, India \\ Address for Correspondance: Neeraj Wadhwa, neeraj.wadhwa@jiit.ac.in
}

\section{Keywords}

Cellulase; Cotton;

Textile Processing;

Enzymes; Scouring.

\begin{abstract}
Various chemicals are used in textiles industries during the different stages of processing of raw fabrics to get finished product. These chemicals are harmful to the environment. Efficient enzymatic treatments are being developed to substitute conventional chemical treatments of textile fibre, which would impart the same modifications to the fibre. In this study, the crude extracts from the corm and peel of Amorphophallus paeoniifolius, were checked for their activity on cotton textile grey fibre and they showed promising results. The treated fibres had weight loss and increased water absorption potential. The crude extract showed high cellulase activity as detected by CMC assay and Filter paper assay and the enzyme was thermostable. This enzyme could be responsible for modifying the cellulose rich surface of the cotton fibre. Moreover, using crude extract from peels of a root would be cost-effective and environment-friendly.(C) 2016 iGlobal Research and Publishing Foundation. All rights reserved.
\end{abstract}

Conference Proceedings: International Conference on Advances in Plant and Microbial Biotechnology (PMB2017); JIIT, Noida: February 02-04, 2017

Indo Global Journal of Pharmaceutical Sciences( ISSN 22491023 ; CODEN- IGJPAI; NLM ID: 101610675) indexed and abstracted in EMBASE(Elsevier), SCIRUS(Elsevier),CABI, CAB Abstracts, Chemical Abstract Services(CAS), American Chemical Society(ACS), Index Copernicus, EBSCO, DOAJ, Google Scholar and many more. For further details, visit http://iglobaljournal.com 